\title{
Gastric Cancer pN3b TNM Finding v8
}

National Cancer Institute

\section{Source}

National Cancer Institute. Gastric Cancer pN3b TNM Finding v8. NCI Thesaurus. Code C133624.

Gastric cancer with metastasis in sixteen or more regional lymph nodes. (from AJCC 8th Ed.) 